International Journal of

Emerging Multidisciplinary Research

\title{
Comparative Analysis of Consumer, Producer, and Expert Perceptions of GM Agricultural Products
}

\author{
Ji-hyun, Lee ${ }^{1}$, Yu-seon, Jang ${ }^{2}$, Hye-won, Jeong ${ }^{3}$, Seon-min, Jin ${ }^{4}$, Sung-Won, Lee ${ }^{5 *}$ \\ ${ }^{1}$ Department of nanomaterial engineering, Chungnam National University, Daejeon 34134, South Korea \\ ${ }^{2}$ Department of Clothing \& Textiles, Chungnam National University, Daejeon 34134, South Korea \\ ${ }^{3-4}$ Department of Information and Statistics, Chungnam National University, Daejeon 34134, South Korea \\ ${ }^{5}$ Strategy Planning Headquarters, KASOM, Seoul, 31035, South Korea
}

\begin{abstract}
Background/Objectives: The purpose of this study is to compare and analyze the differences between producers and experts based on consumers' perceptions of GM agricultural products. Methods/Statistical analysis: To this end, we analyzed how consumers, producers, and experts' perceptions differ with group-specific comparative analysis data on genetically modified agricultural products previously investigated. Findings: As a result of the analysis, it was found that consumers thought genetically modified agricultural products and foods were generally harmful to the human body compared to producers and experts, and fear was also great. When analyzing consumers' perception of whether a genetically modified food labeling system is needed through additional analysis, consumers think it should be marked on the product through a genetically modified food labeling system, but they usually purchase it without checking whether it is marked. Improvements/Applications: Through comparative analysis of consumer perception, a strategic plan for changing consumer perception was proposed along with institutional supplementation of the genetic modification labeling system in the future.
\end{abstract}

\section{Index Terms}

Genetic Modification (GM), Genetically Modified Crop (GMO), Consumer Perception of Genetically Modified Agricultural Products, Genetically Modified Food Labeling System

\section{Corresponding author : Sung-Won, Lee}

lsw1600@gmail.com

- Manuscript received June 26, 2021.

- Revised July 30, 2021; Accepted August 18, 2021.

- Date of publication September 30, 2021.

(c) The Academic Society of Convergence Science Inc.

2546-1583 @ 2017 IJEMR. Personal use is permitted, but republication/redistribution requires IJEMR permission. 


\section{INTRODUCTION}

Unlike in the past, materials are becoming richer due to the emergence and development of ICT. Various foods incorporating ICT technology are emerging, and recently, many changes have been made due to the emergence of data, network, and A.I, which are key technologies of digital transformation[1-3].

Smart farm technology and gene modification technology using smart technology have positive aspects, but on the contrary, they have negative aspects.

Genetically modified (GM) agricultural products and foods can be said to be the biggest alternatives to future food shortages. In fact, GM crops and foods are approved as safe food, but consumers still fear stability.

In particular, in Korea, the food self-sufficiency rate is $47 \%$, but most of the flour, corn, etc., excluding rice, depend on exports. In this situation, we confirm the current situation of consumers' perception of genetically modified agricultural products and food, which are alternatives to food shortage, and suggest alternatives that can raise consumers' perception.

In addition, an empirical analysis was conducted on how consumers perceive genetically modified crops and food labeling agents.

\section{Previous STudies}

\section{A. Genetically Modified (GM) Agricultural products and food products}

Genetically modified agricultural products and foods refer to artificially recombining genes or creating genetically modified organisms and foods with genes or traits that cannot appear by conventional breeding methods[4].

Existing studies have introduced it as one of the ways to solve the food problem through the development of such genetic modification technology[5]. In particular, the agricultural and food industries are benefiting a lot from mass production through resistance to pests and herbicides, reducing production costs of food, and improving taste and quality through such genetic modification technology [6].

On the other hand, consumers acquire a lot of information and react sensitively to risks such as contamination of foreign genes used in genetic modification, compared to limited recognition of the benefits of agricultural products and food through these genetic modification technologies[7-8].

\section{B. Labeling System for Genetically Modified Crops (GMOs)}

Previously, the U.S. did not introduce a mandatory labeling system for GMOs, but the mandatory labeling system has been implemented since 2016, and the GMO labeling system has already been implemented in Europe since 2001. In addition, since 2017, the Food Sanitation Act has been revised to display genetically modified foods[9].

\section{RESEARCH METHODS AND PROCEDURES}

This study compared and analyzed the perception of GMOs by consumers, producers, and experts using group-specific comparative analysis (2015) data on GMO agricultural products in KSDC DB shown the Figure 1. [10].

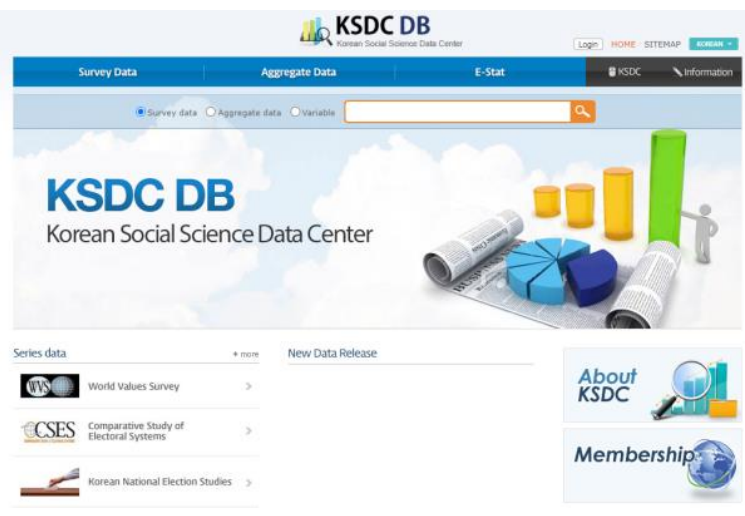

Fig. 1. KSDC DB

First, data was collected from KSDC DB. The collected data was made into data that could be analyzed through a cleansing process. After that, the data were analyzed and the results were derived. It goes through five steps to visualize and utilize the derived results shown the Figure 2[11-13].

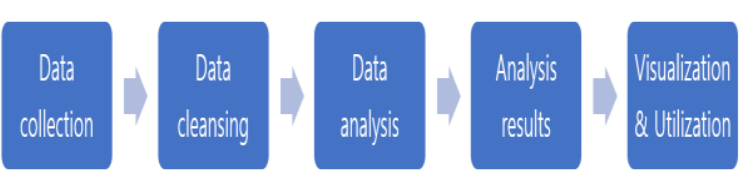

Fig. 2. Analysis process

In this study, analysis was performed using $\mathrm{R}$, an analysis tool, for data analysis[14-15].

\section{RESEARCH RESULTS}

\section{A. Group-specific perceptions of (Genetically Modified Organism: GMO)}

\section{Comparison of perceptions of consumers and}


producers

In order to compare consumers and producers' perceptions of GMOs, six questionnaire items were compared by group through t-test shown the Table 1 .

Table 1. THE RESUltS OF THE T-TEST OF THE CONSUMER AND PRODUCER GROUPS

\begin{tabular}{c|c}
\hline Questionnaireitems. & p-value \\
\hline $\begin{array}{c}\text { What do you think about the effects of } \\
\text { genetically modified agricultural } \\
\text { products on the environment and the } \\
\text { human body? }\end{array}$ & $<2.2 \mathrm{e}-16$ \\
\hline $\begin{array}{c}\text { Do you think the potential risk of } \\
\text { genetically modified agricultural } \\
\text { products on the human body is very } \\
\text { high? }\end{array}$ & $<2.2 \mathrm{e}-16$ \\
\hline $\begin{array}{c}\text { Has the risk of GM agricultural products } \\
\text { and foods on our human body been } \\
\text { scientifically sufficiently proven? }\end{array}$ & $=2.388 \mathrm{e}-12$ \\
\hline $\begin{array}{c}\text { Are GM agricultural products and foods } \\
\text { scary and frightening because they } \\
\text { threaten our food safety? }\end{array}$ & $<2.2 \mathrm{e}-16$ \\
\hline $\begin{array}{c}\text { Can genetically modified foods be } \\
\text { harmful to the human body because they } \\
\text { can have properties that are not found } \\
\text { through conventional food safety tests? }\end{array}$ & $<2.2 \mathrm{e}-16$ \\
\hline $\begin{array}{c}\text { Don't you doubt the safety at all in light } \\
\text { of your experience using GM-related } \\
\text { foods or agricultural products? }\end{array}$ & $=8.551 \mathrm{e}-05$ \\
\hline
\end{tabular}

As a result of the analysis, consumers showed more negative perceptions than producers in all items, and significant results were also shown in differences in perceptions with producers.

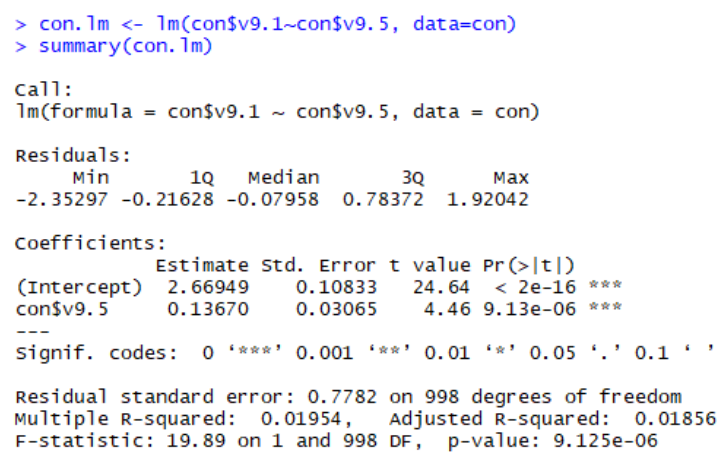

\section{B. Relationship between Genetically Modified Food Labeling System and Purchase}

According to an analysis of the questionnaire items on the genetically modified food labeling system perceived by consumers, the chi-square value is less than 0.05 , so I think it should be marked as genetically modified food, but it can be seen that people usually purchase it without checking whether to display genetically modified food shown the Table 2 .

Table 2. THE RESUlts OF THE T-TEST OF CONSUMERS AND EXPERTS

\begin{tabular}{c|c}
\hline Questionnaireitems. & p-value \\
\hline $\begin{array}{c}\text { What do you think about the effects of } \\
\text { genetically modified agricultural products } \\
\text { on the environment and the human body? }\end{array}$ & $<2.2 \mathrm{e}-16$ \\
\hline $\begin{array}{c}\text { Do you think the potential risk of } \\
\text { genetically modified agricultural products } \\
\text { on the human body is very high? }\end{array}$ & $<2.2 \mathrm{e}-16$ \\
\hline $\begin{array}{c}\text { Are GM agricultural products and food } \\
\text { scary and frightening because they } \\
\text { threaten our food safety? }\end{array}$ & $<2.2 \mathrm{e}-16$ \\
\hline $\begin{array}{c}\text { Can genetically modified foods be } \\
\text { harmful to the human body because they } \\
\text { can have properties that are not found } \\
\text { through conventional food safety tests? }\end{array}$ & $=8.206 \mathrm{e}-14$ \\
\hline $\begin{array}{c}\text { Don't you doubt the safety at all in light of } \\
\text { your experience using GM-related foods } \\
\text { or agricultural products? }\end{array}$ & $=6.984 \mathrm{e}-08$ \\
\hline
\end{tabular}

2. Comparison of perceptions between consumers and experts

In order to see the difference between consumers and experts by group, five questionnaire items were compared by group of consumers and producers through t-test shown the Figure 3. 


\begin{tabular}{|c|c|c|c|c|c|}
\hline & $\begin{array}{c}\text { Makes surt to check } \\
\text { and by it }\end{array}$ & $\begin{array}{l}\text { Buy gentically } \\
\text { modififed foods } \\
\text { withou caring }\end{array}$ & $\begin{array}{l}\text { Ibyy itwithout } \\
\text { checking }\end{array}$ & $\begin{array}{l}\text { Iden' know } \\
\text { geneticilly } \\
\text { modifid food } \\
\text { Ilabeling }\end{array}$ & Row Total \\
\hline $\begin{array}{l}\text { Markitit with the } \\
\text { same image as the } \\
\text { current tone }\end{array}$ & 20 & 54 & 143 & 41 & 258 \\
\hline 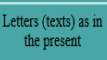 & 11 & 87 & 80 & 29 & 207 \\
\hline $\begin{array}{l}\text { There's no noed to } \\
\text { markik it }\end{array}$ & 2 & 13 & 13 & 4 & 32 \\
\hline $\begin{array}{l}\text { Mark both with } \\
\text { marks and } \\
\text { characters (text) }\end{array}$ & 39 & 82 & 180 & 91 & 392 \\
\hline I don't undersard & 1 & 20 & 80 & 48 & 149 \\
\hline Column Total & 73 & 256 & 496 & 213 & 1038 \\
\hline
\end{tabular}

Fig. 3. Research Model

\section{Conclusion}

In this study, the difference in perception of genetically modified agricultural products and foods by group was verified. The verification results showed that consumers had a negative perception of genetically modified foods compared to producers and expert groups.

As in previous studies, consumers still have a strong negative perception of GMO, and strategic and policy alternatives are needed to change this perception. In order to solve this negative perception, state-led GMO knowledge education is necessary.

In particular, it is necessary to deliver accurate knowledge of GMO and other genes in science and biology textbooks in elementary, middle and high schools. In addition, there is a need to advertise through media such as SNS and blogs to reduce consumer rejection. Finally, as a result of the analysis of the GM labeling system, it was found that consumers considered GM marks and information labeling important, but they did not check them well.

Therefore, it seems necessary to change the mark to stand out immediately or to promote the display system. In the future, further research is needed to verify with variables that can control negative perceptions by adding psychological variables to change the perception of GMOs.

\section{REFERENCES}

[1] Park, S. T., Kim, D. Y., \& Li, G. (2021). An analysis of environmental big data through the establishment of emotional classification system model based on machine learning: focus on multimedia contents for portal applications. Multimedia Tools and Applications, 80(26), 34459-34477.

[2] Kim, D. Y., Park, S. T., \& Ko, M. H. (2018). A study on the analysis of IT-related occupational cluster using big data. IAENG International Journal of Computer Science, 45(1), 711.

[3] Park, S. T., Jung, J. R., \& Liu, C. (2020). A study on policy measure for knowledge-based management in ICT companies: focused on appropriability mechanisms. Information Technology and Management, 21(1), 1-13.

[4] McHughen, A. (2000). A Consumer's Guide to GM Food: From Green Genes to Red Herrings, Oxford: Oxford University Press.

[5] Uzogara S. G. (2000). The Impact of Genetic Modification of Human Foods in the 21st Century: A Review. Biotechnol Advances. 18, 179-206.

[6] Purchase, I. F. H (2005). What Determines the Acceptability of Genetically Modified Food that Can Improve Human Nutrition? Toxicology and Applied Pharmacology, 207, 1927.

[7] Gaskell, G., Alum, N., Wagner, W., Kronberger, N., Torgensern, H., Hampel, J. \& Bardes, J.(2004). GM Foods and the Misperception of Risk Perception. Risk Analysis. 24, 185-194.

[8] Bawa, A. S. \& Anilakumar, K. R.(2013). Genetically Modified Foods: Safety, Risks and Public Concerns-a review, Journal of Food Science and Technology, 50(6).

[9] Jahng K. T. (2017). Biosafety all about GMO 2017, Korea Biosafety Clearing House.

[10] KSDC DB, https://en.ksdedb.kr

[11] Park, S. T., Lee, S. W., \& Kang, T. G. (2018). A study on the trend of cloud service and security through text mining technique. International Journal of Engineering \& Technology, 7(2.33), 127-132.

[12] Li, G., Dai, J. S., Park, E. M., \& Park, S. T. (2017). A study on the service and trend of Fintech security based on textmining: focused on the data of Korean online news. Journal of Computer Virology and Hacking Techniques, 13(4), 249255.

[13] Park, E. M., \& Seo, J. H. (2020). Analysis of Research Trends in Technology Innovation: Focus on SCOPUS DB. Journal of Convergence for Information Technology, 10(8), 120-126.

[14] Kim, I. G, Park S. T, Park, S. S, Kim, M. S, Park J. C \& Jiang, J. (2021). Analysis on Research Trends in Sport Facilities : Focusing on SCOPUS DB . Journal of Industrial Convergence, 19(6), 11-19.

[15] An, S. H., \& Park, S. T. (2020). Exploratory research based on big data for Improving the revisit rate of foreign tourists and invigorating consumption. Journal of Industrial Convergence, 18(6), 19-25. 